\title{
Orchidftgri
}

Vol. 1, No. 1, Bulan Februari Tahun 2021

DOI: http://dx.doi.org/10.35138/orchidagri.v1.i1.255

\section{Pengaruh Penggunaan Pupuk Organik Cair Dan Dinamika Kelompok Terhadap Keberhasilan Usahatani Kedele (Glycine max) Di Kecamatan Cibitung Kabupaten Sukabumi}

\author{
Beny Kurnia Umbara, Maman Haeruman, Musli Rosmali \\ Program Studi Agribisnis Pertanian Fakultas Pertanian, Universitas Winaya Mukti \\ Email: muslirosmali@gmail.com
}

(Received: 04-02-21; Published: 20-02-21)

\begin{abstract}
This study aims to determine how much influence the use of liquid organic fertilizers and group dynamics has on the success of soybean farming. This research was conducted in Cibitung Subdistrict, Sukabumi Regency with the consideration that the soybean plantation area is quite large and is part of a farmer group. The research was started in August 2017 until October 2017. The method used in this research is quantitative method by interviewing and distributing questionnaires. As the research object, namely soybean farmers who use liquid organic fertilizers who are in a farmer group in Cibitung District. The results of the research were analyzed by means of validation tests and reabilitation tests which were further analyzed using path analysis techniques. Partially the results showed that there was a significant effect of using liquid organic fertilizers by $25.2 \%$ and group dynamics by $26.5 \%$ on the success of soybean farming. While simultaneously the effect of both of them on the success of soybean farming was $51.7 \%$, and the remaining $48.3 \%$ came from other variables that were not studied.
\end{abstract}

Keywords: Farming Success, Group Dynamics, Liquid Organic Fertilizer.

\begin{abstract}
ABSTRAK
Penelitian ini bertujuan untuk mengetahui seberapa besar pengaruh penggunaan pupuk organic cair dan dinamika kelompok terhadap keberhasilan usahatani kedelai. Penelitian ini dilakukan di Kecamatan Cibitung Kabupaten Sukabumi dengan pertimbangan luas pertanaman kedelai cukup luas dan tergabung dalam kelompok tani. Penelitian di mulai pada bulanAgustus 2017 sampai bulan Oktober 2017. Metode yang digunakan pada penelitian ini yaitu metode kuantitatif dengan cara wawancara dan membagikan kuisioner. Sebagai objek penelitian yaitu petani kedelai yang menggunakan pupuk organic cair yang berada dalam suatu kelompok tani di Kecamatan Cibitung. Hasil penelitian di analisis dengan uji validasi dan Uji reabilitasi yang selanjutnya di analisis dengan menggunakan teknik analisis jalur (Path Analysis). Secara parsial hasil penelitian menunjukan terdapat pengaruh yang signifikan penggunaan pupuk organic cair sebesar 25,2\% dan dinamika kelompok sebesar 26,5\% terhadap keberhasilan usahatani kedelai. Sedangkan secara simultan pengaruh keduanya terhadapa keberhasilan usahatani kedelai sebesar $51,7 \%$, dan sisanya sebesar $48,3 \%$ berasal dari variabel lain yang tidak diteliti.
\end{abstract}

Kata Kunci: Dinamika Kelompok, Keberhasilan Usahatani, Pupuk Organik Cair. 


\section{PENDAHULUAN}

Indonesia dikenal sebagai Negara agraris yang berarti Negara yang mengandalkan sektor pertanian baik sebagai mata pencaharian maupun sebagai penopang pembangunan. Pembangunan pertanian khususnya sub sektor pertanian tanaman pangan merupakan prioritas pembangunan nasional sejak dikeluarkannya revitalisasi pertanian (Tambunan, 2001).

Hingga saat ini, sektor pertanian masih dominan dalam memberikan kontribusi terhadap pendapatan suatu daerah. Hal ini berguna untuk memenuhi kebutuhan pangan serta meningkatkan pendapatan, taraf hidup dan kesejahteraan petani. Oleh sebab itu maka pemerintah mempunyai kewajiban untuk selalu mengupayakan ketersediaan tanaman pangan melalui berbagai kebijakan.

Salah satu komoditas pertanian yang menjadi perhatian pemerintah adalah komoditas kedelai, dimana tingkat konsumsi masyarakat akan kedelai sangatlah besar sementara disisi lain produksi dalam negri belum mampu untuk memenuhinya sehingga pemerintah masih harus mengimport kedelai dari luar negeri. Prospek pengembangan kedelai di dalam negeri untuk menekan impor cukup baik, mengingat ketersediaan sumberdaya lahan yang cukup luas, iklim yang cocok, teknologi yang telah dihasilkan, serta sumberdaya manusia yang cukup terampil dalam usahatani. Di samping itu, pasar komoditas kedelai masih terbuka lebar.

Permintaan kedelai terus meningkat, namun peningkatan kebutuhan tersebut belum diikuti oleh ketersediaan pasokan yang mencukupi. Pertumbuhan produksi lebih lambat dibanding konsumsi sehingga untuk memenuhi kebutuhan dalam negeri dilakukan impor. Kesenjangan produksi dan konsumsi ini makin nyata karena kedelai juga merupakan bahan baku industri dan pakan. Menurut Goenadi (1997), mengemukakan Departemen Pertanian telah merancang dan melaksanakan program peningkatan produksi kedelai menuju swasembada sejak tahun 1996.

Pengembangan kedelai menghadapi persoalan teknis, sosial, dan ekonomi. Jika kondisi sosial ekonomi kondusif maka secara teknis pengembangan kedelai memiliki potensi dan peluang yang memadai (Sudaryanto, 2004). Dalam berusahatani terdapat banyak faktor yang mempengaruhi keputusan petani dalam mengusahakan komoditi pada lahan yang dimilikinya. Faktor ekonomi meliputi penguasaan modal, harapan keuntungan yang lebih besar dari usahatani yang akan dipilih jika dibandingkan dengan bentuk usahatani lainnya, umur tanaman, kestabilan hasil produksi, mudah tidaknya hasil tersebut dijual sewaktu-waktu.

Faktor teknis di antaranya adalah kualitas dan luas lahan yang dimiliki, ketahanan komoditas terhadap hama dan penyakit, potensi produksi, tingkat adaptasi dan kesesuaian dengan iklim. Faktor sosial meliputi tradisi dan kebiasaan yang telah berlangsung lama, usahatani tetangga, ketersediaan tenaga kerja, kepentingan petani dan keluarganya, tingkat pendidikan dan sebagainya.

Pada dasarnya, pelaksanaan program pengembangan agribisnis kedelai yang ditujukan untuk meningkatkan produksi dan pendapatan masyarakat petani melalui peningkatan penguasaan teknologi usahatani, dengan dukungan ketersediaan sarana produksi. Penguasaan teknologi pasca panen, serta melakukan pembenahan dan peningkatan efisiensi sistem pemasaran yang merupakan faktor kunci keberhasilan. Akan tetapi selama ini kebijakan program tersebut tidak konsisten, sehingga keberhasilannya hanya dicapai pada saat program berlangsung (Zakaria, 2010).

Pengembangan usaha tani kedelai di wilayah Sukabumi mulai berkembang dan memasyarakat terutama di Kecamatan Cibitung Kabupaten Sukabumi secara iklim yang cukup baik menjadi salah satu sentra kedelai di Kabupaten Sukabumi dengan luas tanam dan 
luas panen yang cukup tinggi dibarengi dengan peningkatan produksi dari tahun ke tahun hal ini sangat menunjang dalam upaya peningkatan produksi kedelai Nasional, untuk mencukupi kebutuhan kedelai Nasional, kecamatan Cibitung diharapkan mampu memproduksi tanaman kedelai yang cukup tinggi dari tahun ketahun sehingga diperlukan inovasi dan cara untuk menunjang dalam peningkatanya.

Untuk meningkatkan produksi dan pendapatan petani kedelai salah satu upaya yang dapat digunakan yaitu dengan penggunaan teknologi pupuk organic cair Pupuk organik merupakan pupuk dengan bahan dasar yang diambil dari alam dengan jumlah dan jenis unsur hara yang terkandung secara alami, sementara pupuk anorganik merupakan pupuk buatan pabrik dengan jenis dan kadar unsur hara yang sengaja ditambahkan atau diatur dalam jumlah tertentu. Pupuk organik merupakan salah satu bahan yang sangat penting dalam upaya untuk memperbaiki kebutuhan tanah dan penggunaannya masih sering dibarengi dengan pupuk anorganik atau pupuk kimia buatan pabrik (Musnawar, 2009).

Selain itu pupuk organic dapat diserap dengan cepat oleh tanaman sehingga lebih efektif dibandingkan dengan pupuk kimia. Sehingga dengan efisiensinya pemberian pupuk dapat dimaksimalkan secara efektif oleh tanaman sehigga akan lebih maksimal dalam berproduksi. Dengan beberapa persoalan diatas yaitu menurunya exspor kedelai dan meningkatnya impor kedelai maka diharapkan ada teknologi yang dapat membantu meningkatkan produksi kedelai dengan efisien sehingga dapat meningkatkan pendapatan petani dan dapat membantu kebutuhan kedelai nasional.

Upaya peningkatan produksi kedelai di tingkat petani tidak hanya berkaitandengan aspek teknis dan ekonomis, tetapijuga strategi menggalang partisipasi petani dalam pengembangan kedelai.Untuk mewujudkan partisipasi aktif petani dalam peningkatan produksi kedelaimenuju swasembada dan sekaligus peningkatan pendapatan mereka, perludijalin kerja sama dan koordinasi berbagai pihak terkait dalam pelaksanaan program (Zakaria, 2017).

Pengembangan dan penerapan teknologi budidaya tanaman kedelai tidak terlepas dari individu atau dinamika kelompok tani yang mengelolanya. Dinamika kelompok tani adalah gerakan bersama yang dilakukan oleh anggota kelompok tani secara serentak dan bersama dalam melaksanakan seluruh kegiatan kelompok tani dalam mencapai tujuanya.

Dinamika kelompok merupakan cabang ilmu sosial yang mempelajari perilaku manusiadalam kelompok atau ilmu yang mempelajari tenaga-tenaga yang bekerja dalam kelompok, mencari penyebabnya, dan apa akibatnya terhadap individu maupun kelompok (Amir, 2009). Sebagai salah satu kelompok maka kelompok tani yang merupakan kerja sama dari petani dalam satu wilayah untuk mencapai petani yang berkualitas maka menjadi suatu keharusan bahwa kelompok tani tersebut harus memiliki gerak atau kekuatan yang dapat menentukan dan mempengaruhi perilaku kelompok dan anggota-anggotanya dalam mencapai tujuan secara efektif.

Berdasarkan uraian diatas, hal ini yang yang menjadi bahan pertimbangan penulis untuk menelusuri sejauh mana keberhasilan usaha tani kedelai di kecamatan Cibitung dengan mengungkap factor-faktor yang mempengaruhi keberhasilan usahatani kedelai tersebut agar para petani dapat merasakan manfaat secara finansial untuk meningkatkan kesejahteraan serta dalam rangka mendukung swasenbada pangan melalui program PAJALE. Dari factor yang mempengaruhi terhadap keberhasilan usaha tani kedelai dipilih dua factor yang ingin diteliti lebih dalam yaitu factor penerapan teknologi pemupukan dengan pupuk organik cair dan dinamika kelompok tani. 


\section{METODE PENELITIAN}

Metode yang digunakan dalam penelitian ini adalah metode kualitatif dan kuantitatif, Sedangkan teknik pelaksanaan penelitian menggunakan teknik penelitian survey, yaitu penelitian yang mengambil sample dari satu populasi dan menggunakan kuisioner sebagai alat pengumpulan data yang pokok (Singaribun,1995). Sebagai obyek dalam penelitian ini adalah petani kedelai yang menggunakan Pupuk Organik Cair yang berada dalam suatu kelompok tani di Kecamatan Cibitung Kabupaten Sukabumi. Penelitian ini dilakukan di Kecamatan Cibitung Kabupaten Sukabumi dan lamanya waktu penelitian yang di lakukan selama 3 (tiga) bulan dari bulan Agustus 2017 sampai bulan Oktober 2017.

Untuk memudahkan pengumpulan dan pengolahan data serta memperjelas penelitian, maka untuk variabel-variabel yang diteliti adalah sebagai berikut :

1. Teknologi pupuk organik cair (X1), yaitu cara budidaya tanaman kedelai dengan menggunakan pupuk organik cair berdasarkan rekomendasinya melalui tahap benih, pengelolaan/penanaman, pemupukan dengan pupuk organik cair, pemeliharaan tanaman dari gangguan opt, dan penanganan panen dan pasca panen.

2. Dinamika kelompok tani (X2) adalah adalah sesuatu yang mengandung arti tenaga kekuatan, selalu bergerak, berkembang, dan dapat menyesuaikan diri secara memadai terhadap keadaan dari sekumpulan orangorang tani atau petani yang terikat secara informal dalam suatu wilayah kelompok atas dasar keserasian dan kebutuhan bersama serta berada dilingkungan pengaruh dan dipimpin oleg seorang kontak tani.

3. Keberhasilan Usahatani adalah seseorang mengalokasikan sumber daya yang ada secara efektif dan efisien untuk memperoleh keuntungn yang tinggi pada waktu tertentu.
Dikatakan efektif bila petani dapat mengalokasikan sumberdaya yang mereka miliki sebaik-baiknya, dan dapat dikatakan efisien bila pemanfaatan sumberdaya tersebut mengeluarkan output yang melebihi input.

Data yang digunakan dalam penelitian ini adalah data primer dan data sekunder. Data primer diperoleh dari wawancara langsung dengan petani kedele yang melakukan usaha tani kedele dengan penggunaan pupuk organik cair dan Non organik cair (kimia) pada musim tanam tahun 2017, sedangkan data sekunder diperoleh dari instansi atau dinas terkait, yaitu : Kantor Kecamatan, Dinas Pertanian Kabupaten Sukabumi dan literatur lainnya yang mendukung terhadap topik penelitian

Teknik pengumpulan data dilakukan dengan cara wawancara dan kuesioner terhadap petani kedele yang mnggunakan Pupuk Organik Cair yang tergabung dalam kelompok tani. Berdasarkan catatan petani kedele di kecamatan Cibitung pada musim tanam 2017 menanam kedele seluas 320 Ha. Dari luasan tesebut perkiraan jumlah petaninya sebanyak 235 orang yang berusahatani Kedele dengan teknologi pupuk organik cair. Pada penelitian ini teknik pengambilan sampling menggunakan metode slovin, dengan menggunakan rumus:

$$
\mathbf{n}=\mathbf{N} / \mathbf{N}(\mathbf{d})^{2}+\mathbf{1}
$$

Keterangan: $\mathrm{n}=$ sampel; $\mathrm{N}=$ populasi; $\mathrm{d}=$ nilai presisi $90 \%$ atau sig. $=0,10$.

Validitas data penelitian ditentukan oleh proses pengukuran yang akurat. Suatu kuesioner dikatakan valid jika pertanyaan pada kuesioner mampu untuk mengungkapkan sesuatu yang diukur oleh kuesioner tersebut. Dengan kata lain, instrumen tersebut dapat mengukur butirbutir dalam suatu daftar (konstruk) sesuai dengan yang diharapkan peneliti (Supomo and Indriantoro, 2002). 
Uji Reliabilitas adalah data untuk mengukur suatu kuesioner yang merupakan indikator dari variabel atau konstruk. Suatu kuesioner dikatakan reliabel atau handal jika jawaban seseorang terhadap pernyataan adalah konsisten atau stabil dari waktu ke waktu. Kehandalan yang menyangkut ke konsistenan jawaban jika diujikan berulang pada sampel yang berbeda (Ghozali, 2005).

\section{HASIL DAN PEMBAHASAN}

\section{Uji Validitas dan Reliabilitas}

Berdasarkan rekapitulasi hasil pengujian validitas instrumen, diperoleh informasi bahwa seluruh pernyataan yang diajukan dalam mengukur penggunaan pupuk organik memiliki nilai r-hitung di atas nilai r-tabel $(0,361)$ yang menunjukan bahwa seluruh pernyataan yang diajukan sudah dinyatakan valid. Dan dari hasil pengujian reliabilitas, diperoleh nilai koefisien alpha sebesar 0,628>0,6 dan dinyatakan reliabel. Dengan demikian dapat disimpulkan bahwa alat ukur mengenai penggunaan pupuk organik sudah memenuhi syarat untuk digunakan dalam penelitian. Sedangkan rekapitulasi hasil pengujian validitas instrumen, diperoleh informasi bahwa seluruh pernyataan yang diajukan dalam mengukur dinamika kelompok tani memiliki nilai r-hitung di atas nilai r-tabel $(0,361)$ yang menunjukan bahwa seluruh pernyataan yang diajukan sudah dinyatakan valid. Dan dari hasil pengujian Tabel 1. Kriteria Rata-Rata Skor Tanggapan Responden reliabilitas, diperoleh nilai koefisien alpha sebesar 0,753>0,6 dan dinyatakan reliabel.

Dengan demikian dapat disimpulkan bahwa alat ukur mengenai dinamika kelompok tani sudah memenuhi syarat untuk digunakan dalam penelitian. Selanjutnya rekapitulasi hasil pengujian validitas instrumen, diperoleh informasi bahwa seluruh pernyataan yang diajukan dalam mengukur keberhasilan usaha tani kedelai memiliki nilai r-hitung di atas nilai r-tabel $(0,361)$ yang menunjukan bahwa seluruh pernyataan yang diajukan sudah dinyatakan valid. Dan dari hasil pengujian reliabilitas, diperoleh nilai koefisien alpha sebesar 0,852 > 0,6 dan dinyatakan reliabel. Dengan demikian dapat disimpulkan bahwa alat ukur mengenai keberhasilan usaha tani kedelai sudah memenuhi syarat untuk digunakan dalam penelitian.

\section{Analisis Deskriptif}

Gambaran data hasil penelitian dapat digunakan untuk memperkaya pembahasan, melalui gambaran data tanggapan responden dapat diketahui bagaimana tanggapan responden terhadap setiap variabel yang sedang diteliti. Agar lebih mudah menginterpretasikan variabel yang sedang diteliti, dilakukan kategorisasi terhadap skor tanggapan responden dengan menggunakan rata-rata yang diperoleh dari hasil perbandingan antara skor total dengan jumlah responden. Adapun kriteria rata-rata skor tanggapan responden tersebut dapat dilihat pada tabel berikut:

\begin{tabular}{||c|c|c||}
\hline No & Nilai Rata-Rata & Kriteria \\
\hline \hline 1 & $1,00-1,80$ & Sangat Tidak Baik \\
\hline 2 & $1,81-2,60$ & Tidak Baik \\
\hline 3 & $2,61-3,40$ & Kurang Baik \\
\hline 4 & $3,41-4,20$ & Sangat Baik \\
\hline 5 & $4,21-5,00$ & \\
\hline
\end{tabular}

25|OrchidAgri: Vol 1, No 1, Bulan Februari Tahun 2021 
Tanggapan

Responden

Penggunaan Pupuk Organik Cair

Alat ukur mengenai penggunaan pupuk organik cair dalam penelitian ini diukur dengan menggunakan lima dimensi yang dioperasionalisasikan kedalam lima item pernyataan yang relevan. Tanggapan responden mengenai penggunaan pupuk organik cair. Dari hasil penelitian diketahui bahwa nilai rata-rata tertinggi diperoleh sebesar 3,89 berkenaan dengan sistem dan teknik pemeliharaan yang dilakukan petani, sedangkan nilai rata-rata terendah diperoleh sebesar 3,16 berkenaan dengan sistem perlakuan terhadap benih. Secara keseluruhan, nilai rata-rata yang diperoleh sebesar 3,56 yang berada dalam kelas interval antara 3,41 - 420 dan berada dalam kategori tinggi. Sehingga dapat diambil kesimpulan bahwa penggunaan pupuk organik cair terkategorikan tinggi.

\section{Tanggapan Responden Mengenai Dinamika Kelompok Tani}

Alat ukur mengenai dinamika kelompok tani dalam penelitian ini diukur dengan menggunakan delapan dimensi yang dioperasionalisasikan kedalam tiga belas item pernyataan yang relevan. Tanggapan-tanggapan responden mengenai dinamikan kelompok tani dapat dilihat pada uraian-uraian berikut:

Tabel 2. Tanggapan Responden Mengenai Dinamika Kelompok Tani

\begin{tabular}{|c|c|c|c|c|c|c|c|c|c|}
\hline \multirow{2}{*}{ No } & \multirow{2}{*}{ Pernyataan } & \multicolumn{5}{|c|}{ בJawaban Responden } & \multirow{2}{*}{$\begin{array}{l}\text { Total } \\
\text { Skor }\end{array}$} & \multirow{2}{*}{$\begin{array}{l}\text { Rata- } \\
\text { Rata }\end{array}$} & \multirow{2}{*}{ Kategori } \\
\hline & & ST & $\mathbf{T}$ & CT & $\mathbf{R}$ & SR & & & \\
\hline 1 & $\begin{array}{l}\text { Keterkaitan pengurus dan anggota } \\
\text { kelompok terhadap penentuan tujuan } \\
\text { kelompok }\end{array}$ & 5 & 34 & 31 & 0 & 0 & 254 & 3,22 & Cukup Tinggi \\
\hline 2 & Struktur komunikasi & 13 & 41 & 12 & 4 & 0 & 273 & 3,46 & Tinggi \\
\hline 3 & $\begin{array}{l}\text { Struktur tugas dan pengambilan } \\
\text { keputusan }\end{array}$ & 4 & 42 & 24 & 0 & 0 & 260 & 3,29 & Cukup Ting \\
\hline 4 & Sarana terjadinya interaksi & 7 & 43 & 16 & 4 & 0 & 263 & 3,33 & Cukup Tinggi \\
\hline 5 & Membentuk kerjasama & 3 & 44 & 21 & 2 & 0 & 258 & 3,27 & Cukup Tinggi \\
\hline 6 & Memudahkan pekerjaan & 14 & 45 & 9 & 2 & 0 & 281 & 3,56 & Tinggi \\
\hline 7 & Mengatasi pekerjaan & 1 & 49 & 20 & 0 & 0 & 261 & 3,30 & Cukup Tinggi \\
\hline 8 & Menciptakan iklim demokrasi & 0 & 45 & 21 & 4 & 0 & 251 & 3,18 & Cukup Tinggi \\
\hline 9 & $\begin{array}{l}\text { Upaya untuk memelihara kehidupan } \\
\text { dan pengembangan kelompok }\end{array}$ & 0 & 30 & 28 & 12 & 0 & 228 & 2,89 & Cukup Tinggi \\
\hline 10 & $\begin{array}{l}\text { Homogenitas kelompok, } \\
\text { kepemimpinan dan interritas anggota }\end{array}$ & 0 & 25 & 34 & 11 & 0 & 224 & 2,84 & Cukup Tinggi \\
\hline 11 & $\begin{array}{l}\text { Keramahan dan Kenyamanan } \\
\text { Lingkungan fisik }\end{array}$ & 0 & 11 & 47 & 12 & 0 & 209 & 2,65 & Cukup Tinggi \\
\hline 12 & $\begin{array}{l}\text { Tekanan dari dalam dan dari luar } \\
\text { kelompok }\end{array}$ & 0 & 15 & 49 & 6 & 0 & 219 & 2,77 & Cukup Tinggi \\
\hline 13 & $\begin{array}{l}\text { Tercapainya tujuan keberhasilan } \\
\text { secara fisik dan non fisik }\end{array}$ & 0 & 16 & 45 & 9 & 0 & 217 & 2,75 & Cukup Tinggi \\
\hline \multicolumn{7}{|c|}{ Total } & 3198 & 3,11 & Cukup Ting \\
\hline
\end{tabular}


Tabel di atas menjelaskan distribusi tanggapan-tanggapan responden mengenai dinamika kelompok tani. Dari hasil penelitian diketahui bahwa nilai rata-rata tertinggi diperoleh sebesar 3,56 berkenaan dengan indikator memudahkan pekerjaan, sedangkan nilai rata-rata terendah diperoleh sebesar 2,65 berkenaan dengan keramahan dan kenyamanan lingkungan fisik. Secara keseluruhan, nilai ratarata yang diperoleh sebesar 3,11 yang berada dalam kelas interval antara 3,41 - 4,20 dan berada dalam kategori cukup tinggi. Sehingga dapat diambil kesimpulan bahwa dinamika kelompok tani pada petani kelompok tani kedelei dinilai cukup tinggi.

\section{Tanggapan Responden Mengenai Keberhasilan Usaha Tani}

Alat ukur mengenai keberhasilan usaha tani kedelai dalam penelitian ini diukur dengan menggunakan dua dimensi yang dioperasionalisasikan kedalam dua item pernyataan yang relevan. Tanggapan-tanggapan responden mengenai keberhasilan usaha tani kedelai dapat dilihat pada uraian-uraian berikut:

Tabel 3. Tanggapan Responden Mengenai Keberhasilan Usaha Tani Kedelai

\begin{tabular}{|c|c|c|c|c|c|c|c|c|c|}
\hline \multirow{2}{*}{ No } & \multirow{2}{*}{ Pernyataan } & \multicolumn{5}{|c|}{ Jawaban Responden } & \multirow{2}{*}{$\begin{array}{l}\text { Total } \\
\text { Skor }\end{array}$} & \multirow{2}{*}{$\begin{array}{l}\text { Rata- } \\
\text { Rata }\end{array}$} & \multirow{2}{*}{ Kategori } \\
\hline & & ST & $\mathbf{T}$ & CT & $\mathbf{R}$ & SR & & & \\
\hline 1 & $\begin{array}{l}\text { Jumlah Panen Total yang dihasilkan } \\
\text { satu kali musim tanam }\end{array}$ & 3 & 65 & 2 & 0 & 0 & 281 & 3,56 & Tinggi \\
\hline 2 & $\begin{array}{l}\text { Penerimaan dikurangi biaya produksi } \\
\text { dalam satuan rupiah }\end{array}$ & 3 & 46 & 21 & 0 & 0 & 262 & 3,32 & Cukup Tinggi \\
\hline \multicolumn{7}{|c|}{ Total } & 543 & 3,44 & Tinggi \\
\hline
\end{tabular}

Tabel di atas menjelaskan distribusi tanggapan-tanggapan responden berkenaan dengan keberhasilan usaha tani kedelai. Dari hasil penelitian diketahui bahwa nilai rata-rata keseluruhan yang diperoleh sebesar 3,44. Nilai tersebut berada dalam kelas interval antara 3,414,20 dan berada dalam kategori tinggi. Sehingga dapat diambil kesimpulan bahwa petani kedelai memiliki tingkat keberhasilan usaha yang terkategorikan tinggi.

Produksi, luas lahan, pupuk, tenaga kerja, pendidikan dan pengalaman bertani sangat

\section{Pengaruh Penggunaan Pupuk Organik Cair dan Dinamika Kelompok terhadap Keberhasilan Usahatani Kedelai}

Sebagaimana telah dijelaskan pada bab sebelumnya bahwa tujuan utama penelitian ini adalah untuk mengetagui pengaruh penggunaan pupuk organik cair dan dinamika kelompok terhadap keberhasilan usahatani kedelai dengan berpengaruh terhadap usahatani kedelai di daerah penelitian (Arifin and Sahrawi, 2014).

Produksi petani kedelai dipengaruhi oleh variabel luas lahan dan jumlah pupuk urea sedangkan variabel jumlah bibit serta jumlah pupuk kandang dan Phonska tidak berpengaruh terhadap produksi kedelai. Untuk variabel pendapatan petani kedelai dipengaruhi oleh harga produk, harga pupuk TSP, harga pestisida dan harga tenaga kerja (Dwi Nugroho et al., 2013).

menggunakan analisis jalur (path analyzis). Untuk melakukan analisis jalur, diperlukan data sekurang-kurangnya memiliki skala interval, sehingga harus dilakukan transformasi data dari ordinal menjadi skala interval menggunakan Methode of Succesive Interval (MSI). Setelah itu, masing-masing variabel bebas dan variabel terikat dijumlahkan skor total intervalnya. Data 
inilah yang kemudian akan dianalisis dengan menggunakan analisis jalur.

Tahap kedua dalam berusatanikedelai adalah melakukan pemupukan dasaryang diberikan pada saat melakukanpenugalan. Dosis pupuk yang digunakansangat tergantung pada jenis lahan dan kondisitanah. Padatanah subur atau tanah bekasditanami padi dengan dosis pupuk tinggi, pemupukan tidak diperlukan. Pada tanah yangkurang subur, pemupukan dapat menaikkanhasil. Pemupukan dilakukan sebanyak tigakali, yaitu pemupukan dasar, pemupukan padaumur 25 hari danpemupukan pada umur 45 hari (Nugrahana et al., 2017).
Hal ini menunjukan bahwa secara simultan, penggunaan pupuk organik cair $\left(\mathrm{X}_{1}\right)$ dan dinamika kelompok $\left(\mathrm{X}_{2}\right)$ tidak berpengaruh signifikan terhadap keberhasilan usahatani kedelai (Y). $\mathrm{H}_{1}=$ sekurang-kurangnya ada sebuah PYxi $\neq 0, \mathrm{i}=1,2$

Hal ini menunjukan bahwa secara simultan, penggunaan pupuk organik cair $\left(\mathrm{X}_{1}\right)$ dan dinamika kelompok $\left(\mathrm{X}_{2}\right)$ berpengaruh signifikan terhadap keberhasilan usahatani kedelai $(Y)$.

Taraf signifikansi $(\alpha): 0,05$

Kriteria uji : tolak $\mathrm{H}_{0}$ jika nilai F-hitung > Ftabel, terima $\mathrm{H}_{0}$ jika nilai $\mathrm{F}$ hitung $<$ F-tabel

Nilai statistik uji $\mathrm{F}$ dapat diketahui dari tabel output berikut:

\section{Pengujian Hipotesis}

\section{Pengujian Hipotesis Simultan}

$$
\mathrm{H}_{0}=\mathrm{PYX}_{1}=\mathrm{PYX}_{2}=0
$$

Tabel 4. Pengujian Hipotesis Simultan

ANOV A

\begin{tabular}{|ll|r|r|r|r|r|}
\hline Model & & Sum of & & & & \\
\hline 1 & Regression & 45,630 & df & Mean Square & F & Sig. \\
& Residual & 42,747 & 67 & 22,815 & 35,759 &, $000^{\mathrm{a}}$ \\
& Total & 88,377 & 69 &, 638 & & \\
&
\end{tabular}

a. Predictors: (Constant), Dinamika Kelompok, Penggunaan Pupuk

b. Dependent Variable: Keberhasilan Usaha

Berdasarkan tabel output di atas, diketahui bahwa nilai $F_{\text {hitung }}$ yang diperoleh sebesar 35,759. Nilai ini akan dibandingkan dengan nilai $F_{\text {tabel }}$ pada tabel distribusi $F$. Dengan $\alpha=0,05, \mathrm{db}_{1}=2$ dan $\mathrm{db}_{2}=67$, diperoleh nilai $\mathrm{F}_{\text {-tabel }}$ sebesar 3,134. Dari nilai-nilai tersebut terlihat bahwa nilai $F_{\text {hitung }}$ yang diperoleh sebesar 35,759 lebih besar dari nilai $F_{\text {tabel }} 3,134$. Sesuai dengan kriteria pengujian hipotesis bahwa $\mathrm{H}_{0}$ ditolak dan $\mathrm{H}_{1}$ diterima, artinya secara simultan penggunaan pupuk organik cair $\left(\mathrm{X}_{1}\right)$ dan dinamika kelompok $\left(\mathrm{X}_{2}\right)$ berpengaruh signifikan terhadap keberhasilan usahatani kedelai (Y). Jika disajikan dalam gambar, nilai F-hitung dan Ftabel tersebut dapat dilihat sebagai berikut: 


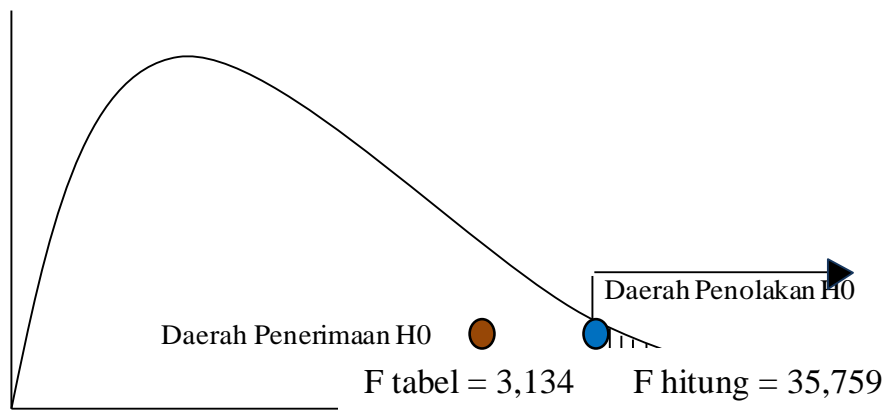

Gambar 1 Kurva Uji Hipotesis Simultan $\mathrm{X}_{1}$ dan $\mathrm{X}_{2}$ terhadap Y

\section{Pengujian Hipotesis Parsial}

\section{Pengujian Hipotesis Parsial $\mathbf{X}_{\mathbf{1}}$}
$\mathrm{H}_{0}: \mathrm{PYX}_{1}=0$ Artinya, secara parsial penggunaan pupuk organik cair tidak berpengaruh signifikan terhadap keberhasilan usahatani padi sawah.

$\mathrm{H}_{1}: \mathrm{PYX}_{1} \neq 0$ Artinya, secara parsial penggunaan pupuk organik cair berpengaruh signifikan terhadap keberhasilan usahatani padi sawah.

Dengan taraf signifikansi 0,05

Kriteria: Tolak $\mathrm{H}_{0}$ jika t hitung < dari t tabel, terima dalam hal lainnya

Dengan menggunakan SPSS, diperoleh hasil uji hipotesis parsial $\mathrm{X}_{1}$ sebagai berikut:

Tabel 5. Pengujian Hipotesis Parsial $\mathrm{X}_{1}$

\section{Coefficients̊}

\begin{tabular}{|c|c|c|c|c|c|c|}
\hline \multirow{2}{*}{\multicolumn{2}{|c|}{ Model }} & \multicolumn{2}{|c|}{$\begin{array}{c}\text { Unstandardized } \\
\text { Coefficients }\end{array}$} & \multirow{2}{*}{$\begin{array}{c}\text { Standardized } \\
\text { Coefficients } \\
\text { Beta }\end{array}$} & \multirow[b]{2}{*}{$\mathrm{t}$} & \multirow[b]{2}{*}{ Sig. } \\
\hline & & $\mathrm{B}$ & Std. Error & & & \\
\hline \multirow[t]{3}{*}{1} & (Constant) & $-1,954$ & ,890 & & $-2,195$ &, 032 \\
\hline & Penggunaan Pupuk & ,231 &, 043 & ,465 & 5,403 &, 000 \\
\hline & Dinamika Kelompok & , 123 & ,022 & ,479 & 5,563 &, 000 \\
\hline
\end{tabular}

a. Dependent Variable: Keberhasilan Usaha

Berdasarkan tabel di atas terlihat bahwa nilai $t_{\text {hitung }}$ yang diperoleh sebesar 5,403. Nilai ini akan dibandingkan dengan nilai $t_{\text {tabel }}$ pada tabel distribusi t. Dengan $\alpha=0,05, \mathrm{df}=\mathrm{n}-\mathrm{k}-1=70$ $2-1=67$, untuk pengujian dua sisi diperoleh nilai $\mathrm{t}_{\text {tabel }}$ sebesar \pm 1 ,996. Dari nilai-nilai tersebut terlihat bahwa nilai $t_{\text {hitung }}$ yang diperoleh sebesar 5,403 berada diluar nilai $t_{\text {tabel }}(-1,996$ dan 1,996$)$.
Sesuai dengan kriteria pengujian hipotesis bahwa $\mathrm{H}_{0}$ ditolak dan $\mathrm{H}_{1}$ diterima, artinya secara parsial penggunaan pupuk organik cair berpengaruh signifikan terhadap keberhasilan usahatani kedelai. Jika disajikan dalam grafik, nilai t-hitung dan t-tabel tersebut dapat dilihat pada gambar berikut ini: 


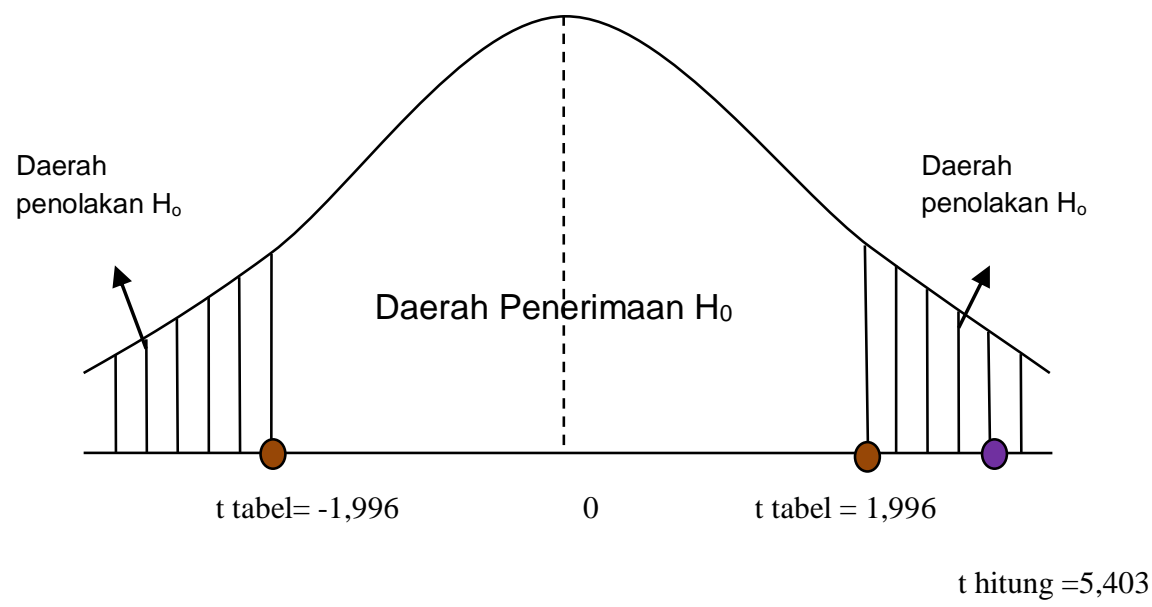

Gambar 2. Uji Hipotesis Parsial $\mathrm{X}_{1}$

signifikan terhadap keberhasilan usahatani padi sawah.

Dengan taraf signifikansi 0,05

\section{Pengujian Hipotesis Parsial $\mathbf{X}_{\mathbf{2}}$}

$\mathrm{H}_{0}: \mathrm{PYX}_{2}=0$ Artinya, secara parsial dinamika kelompok tidak berpengaruh signifikan terhadap keberhasilan usahatani padi sawah.

$\mathrm{H}_{1}: \mathrm{PYX}_{2} \neq 0$ Artinya, secara parsial dinamika kelompok berpengaruh
Kriteria : Tolak $\mathrm{H}_{0}$ jika $\mathrm{t}$ hitung $<$ dari $\mathrm{t}$ tabel, terima dalam hal lainnya

Dengan menggunakan SPSS, diperoleh hasil uji hipotesis parsial $\mathrm{X}_{2}$ sebagai berikut:

Tabel 6. Pengujian Hipotesis Parsial $\mathrm{X}_{2}$

Coefficients

\begin{tabular}{|rl|r|r|r|r|r|}
\hline \multirow{2}{*}{ Model } & \multicolumn{2}{|c|}{$\begin{array}{c}\text { Unstandardized } \\
\text { Coefficients }\end{array}$} & \multicolumn{2}{c|}{$\begin{array}{c}\text { Standardized } \\
\text { Coefficients }\end{array}$} & \\
\cline { 3 - 5 } & & \multicolumn{1}{|c|}{$\mathrm{B}$} & \multicolumn{1}{|c|}{ Std. Error } & \multicolumn{1}{|c|}{ Beta } & \multicolumn{1}{c|}{ S } \\
\hline & (Constant) & $-1,954$ &, 890 & & $-2,195$ &, 032 \\
& Penggunaan Pupuk &, 231 &, 043 &, 465 & 5,403 &, 000 \\
& Dinamika Kelompok &, 123 &, 022 &, 479 & 5,563 &, 000 \\
\hline
\end{tabular}

a. Dependent Variable: Keberhasilan Usaha

Berdasarkan tabel di atas terlihat bahwa nilai $t_{\text {hitung }}$ yang diperoleh sebesar 5,563. Nilai ini akan dibandingkan dengan nilai $t_{\text {tabel }}$ pada tabel distribusi t. Dengan $\alpha=0,05, \mathrm{df}=\mathrm{n}-\mathrm{k}-1=70$ $2-1=67$, untuk pengujian dua sisi diperoleh nilai $t_{\text {tabel }}$ sebesar \pm 1 ,996. Dari nilai-nilai tersebut terlihat bahwa nilai $t_{\text {hitung }}$ yang diperoleh sebesar 5,563 berada diluar nilai $t_{\text {tabel }}(-1,996$ dan 1,996).
Sesuai dengan kriteria pengujian hipotesis bahwa $\mathrm{H}_{0}$ ditolak dan $\mathrm{H}_{1}$ diterima, artinya secara parsial dinamika kelompok berpengaruh signifikan terhadap keberhasilan usahatani kedelai. Jika disajikan dalam grafik, nilai thitung dan t-tabel tersebut dapat dilihat pada gambar berikut ini: 


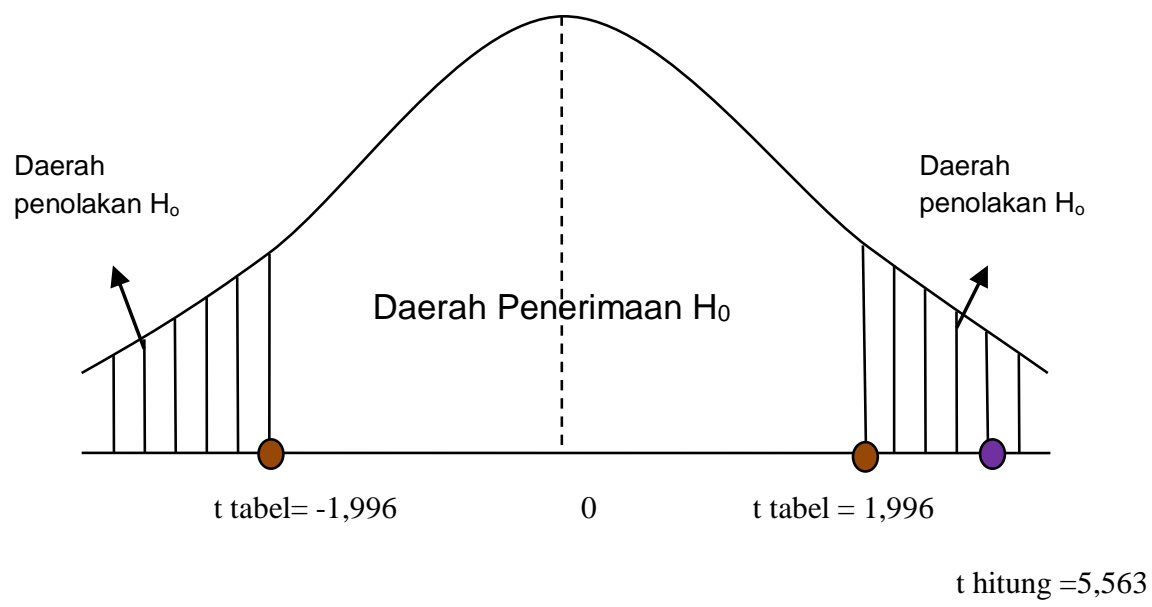

Gambar 3. Uji Hipotesis Parsial $\mathrm{X}_{2}$

\section{Pengaruh Langsung dan Tidak Langsung}

Berdasarkan uraian-uraian di atas diperoleh kesimpulan bahwa bahwa penggunaan pupuk organik cair dan dinamika kelompok berpengaruh signifikan terhadap keberhasilan usaha tani kedelai. Untuk melihat lebih jauh tentang besar pengaruh langsung dan tidak langsung dari masing-masing variabel bebas terhadap variabel terikat, berikut disajikan perhitungan pengaruh langsung dan tidak langsungnya.

Tabel 7. Pengaruh Langsung dan Tidak Langsung Dari $\mathrm{X}_{1}$ dan $\mathrm{X}_{2}$ Terhadap $\mathrm{Y}$

\begin{tabular}{|c|c|c|c|c|c|c|}
\hline \multirow[t]{2}{*}{ Variabel } & \multirow[t]{2}{*}{$\begin{array}{c}\text { Koefisien } \\
\text { Jalur }\end{array}$} & \multirow[t]{2}{*}{$\begin{array}{c}\text { Pengaruh } \\
\text { Langsung } \\
(\%)\end{array}$} & \multicolumn{2}{|c|}{$\begin{array}{l}\text { Pengaruh tidak } \\
\text { langsung } \\
\text { (melalui), dalam } \\
\%\end{array}$} & \multirow[t]{2}{*}{$\begin{array}{c}\text { Total } \\
\text { Pengaruh } \\
\text { Tidak } \\
\text { Langsung } \\
(\%)\end{array}$} & \multirow[t]{2}{*}{ Total Pengaruh $(\%)$} \\
\hline & & & $\mathrm{X}_{1}$ & $\mathrm{X}_{2}$ & & \\
\hline $\mathrm{X}_{1}$ & 0,465 & 21,6 & - & 3,5 & 3,5 & 25,2 \\
\hline $\mathrm{X}_{2}$ & 0,479 & 22,9 & 3,5 & - & 3,5 & 26,5 \\
\hline \multicolumn{6}{|c|}{ Total Pengaruh } & 51,6 \\
\hline
\end{tabular}

- Penggunaan pupuk organik cair $\left(X_{1}\right)$ memberikan pengaruh langsung terhadap keberhasilan usaha tani kedelai $(\mathrm{Y})$ sebesar 21,6\% dan pengaruh tidak langsung melalui dinamika kelompok $\left(\mathrm{X}_{2}\right)$ sebesar 3,5\%, sehingga total pengaruh yang diberikan penggunaan pupuk organik cair terhadap keberhasilan usaha tani sebesar 25,2\%.

- Dinamika kelompok $\left(\mathrm{X}_{2}\right)$ memberikan pengaruh langsung terhadap keberhasilan usaha tani kedelai (Y) sebesar 22,9\% dan pengaruh tidak langsung melalui penggunaan pupuk organik cair $\left(\mathrm{X}_{1}\right)$ sebesar $3,5 \%$, sehingga total pengaruh yang diberikan dinamika kelompok terhadap keberhasilan usaha tani sebesar $26,5 \%$.

\section{KESIMPULAN DAN SARAN}

Berdasarkan hasil analisis data dan pembahasan yang telah dijelaskan pada bab sebelumnya, maka penulis mengambil beberapa kesimpulan sebagai berikut: Secara parsial, 
pengguna pupuk organik cair berpengaruh signifikan terhadap keberhasilan usaha tani kedelai di Kecamatan Cibitung Kabupaten Sukabumi dengan kontribusi yang diberikan sebesar 25,2\%.

Secara parsial, dinamika kelompok berpengaruh signifikan terhadap keberhasilan usaha tani kedelai di Kecamatan Cibitung Kabupaten Sukabumi dengan kontribusi yang diberikan sebesar $26,2 \%$.

Secara simultan, penggunaan pupuk organik cair dan dinamika kelompok berpengaruh signifikan terhadap keberhasilan usaha tani kedelai di Kecamatan Cibitung Kabupaten Sukabumi dengan kontribusi yang diberikan sebesar 51,6\%, sedangkan 48,4\% lainnya merupakan kontribusi dari variabel lain yang tidak diteliti.

\section{SARAN}

Sebagai tindak lanjut dari kemamfaatan penelitian ini maka disampaikan saran sebagai berikut:

1. Bagi para petani kedele yang menerapkan teknologi pemupukan organic cair sebaiknya terus mengembangkan dan menerpakan teknologi ini untuk meningkatkan hasil pertanianya.

2. Bagi para petani yang kurang aktif atau belum tergabung dalam kegiatan kelompok tani agar bisa untuk mengikutinya sesuai dengan rencana kerja kelompok yang sudah di susun dan disepakati sebelumnya oleh pengurus dan anggota

3. Perlu penelitian lebih lanjut terkait penerapan teknologi pupuk organic cair dan dinamika kelompok tani terutama adanya faktor lain selain penelitian ini yang dapat mempengaruhi peningkatan hasil pertanian.

\section{DAFTAR PUSTAKA}

Amir, A.M. 2009. Penerapan Dinamika Kelompok. J. Acad. Fisip Untad I: 120
130.

https://media.neliti.com/media/publications /28572-ID-penerapan-dinamika-

kelompok.pdf.

Arifin, Z., and Sahrawi. 2014. Analisa Usahatani Kedelai Varietas Wilis Pada Lahan Sawah Tadah Hujan Di Desa Klompang Barat Kecamatan. J. Ilm. Fak. Pertan. 5(2): 2637.

http://download.garuda.ristekdikti.go.id/art icle.php?article $=829620 \& \mathrm{val}=13464 \&$ title

Dwi Nugroho, A., F. Rohmah, A. Hasyim Al Rosyid, and K. Suratiyah. 2013. Faktor yang Mempengaruhi Produksi dan Pendapatan Petani Kedelai di Kecamatan Paliyan Gunung Kidul. J. Chem. Inf. Model. 53(9): 1689-1699.

Geonadi. 1997. Kompos Bioaktif dari Tandan Kosong Kelapa Sawit. Kumpulan Malaba Pertemuan Teknis Biotek

Ghozali, I. 2005. Aplikasi Analisis Multivariate Dengan Program SPSS. Edisi Ke Tiga. Penerbit Universitas Diponegoro, Semarang

Musnawar, E.I. 2009. Pupuk Organik. Penebar Swadaya. Jakarta

Nugrahana, G., D.H. Sujaya, and M.N. Yusuf. 2017. Analisis Usahatani Kedelai (Glycine Max) (Studi Kasus pada Kelompok Tani Harapan Maju Desa Cigugur Kecamatan Cigugur Kabupaten Pangandaran). J. Ilm. Mhs. AGROINFO GALUH 4(2): 182-187. doi:

http://dx.doi.org/10.25157/jimag.v3i2.712.

Sudaryanto. 2004. Metoda dan Aneka Teknik Analisis. Bahasa Pengantar Penelitian Wahana Kebudayaan Secara Linguistik. Duta Wacana University Press

Supomo, B., and N. Indriantoro. 2002. 
Meotodologi Penelitian Bisnis. Cetakan

Kedua. Penerbit BFEE UGM, Yogyakarta

Tambunan, T.T.H. 2001. Perekonomian Indonesia. Teori dan Temuan Empiris Ghalia Indonesia. Jakarta

Zakaria, A.K. 2010. Kebijakan Pengembangan Budidaya Kedelai Menuju Swasembada Melalui Partisipasi Petani. Anal. Kebijak. Pertan. 8(3): 259-272. https://media.neliti.com/media/publications /56932-ID-kebijakan-pengembangan-budidaya-kedelai.pdf.

Zakaria, A.K. 2017. Program Pengembangan Agribisnis Kedelai Dalam Peningkatan Produksi Dan K Pendapatan Petani. J. Penelit. dan Pengemb. Pertan. 29(4): 147153. doi: 10.21082/jp3.v29n4.2010.p147153. 